\title{
Cyclooxygenase-2 inhibition in colon experimental carcinogenesis
}

\author{
J. F. Noguera Aguilar, I. Amengual Antich¹, A. Plaza Martínez², J. Ibarra de la Rosa ${ }^{3}$, C. Tortajada \\ Collado $^{4}$, A. Gamundí Gamundí ${ }^{5}$ and J. J. Pujol Tugores ${ }^{6}$ \\ Unit of Surgery. Hospital Son Llàtzer. Baleares. ${ }^{1}$ Unit of Pathology. Fundación Hospital Manacor. Baleares. ${ }^{2}$ Service of \\ Vascular Surgery. Hospital Universitario Dr. Peset. Valencia. ${ }^{3}$ Unit of Pathology. Hospital Son Llàtzer. Baleares. \\ ${ }^{4}$ Hospital Universitario Son Dureta. Baleares. ${ }^{5}$ Animal Physiology. UIB. ${ }^{6}$ Unit of Surgery. Hospital Son Llàtzer. Baleares. \\ Instituto Universitario de Investigación en Ciencias de la Salud (IUNICS)
}

\begin{abstract}
Background: an overexpression of cyclooxygenase-2 (COX2) has been seen in colon tumors; therefore, COX-2 specific inhibitors may be used as preventive agents. The aim of this study was to investigate the effect of both selective and non-selective COX-2 inhibitors on the incidence of colonic tumors in a model of chemical carcinogenesis in the rat.

Design: experimental study with 65 male Sprague-Dawley rats randomly assigned to one of four groups: (a) control $(n=20)$, with chemical carcinogenesis using 1-2 dimethylhydrazine (1-2 $\mathrm{DMH})$; (b) acetylsalicylic acid (ASA) ( $\mathrm{n}=15)$, with chemical carcinogenesis and the addition of ASA at $30 \mathrm{mg} / \mathrm{kg}$; (c) low-dose rofecoxib $(n=15)$, with chemical carcinogenesis and the addition of rofecoxib at a dose of $1.2 \mathrm{mg} / \mathrm{kg}$; (d) high-dose rofecoxib $(\mathrm{n}=15)$, with carcinogenesis and the addition of rofecoxib at $3 \mathrm{mg} / \mathrm{kg}$. Carcinogenic induction was performed with 1-2 DMH at a weekly dose of $25 \mathrm{mg} / \mathrm{kg}$ for 18 weeks. The main parameter evaluated was percentage of neoplastic colonic tissue, which relates tumor surface area to colon surface area.

Results: rofecoxib at a dose of $3 \mathrm{mg} / \mathrm{kg}$ significantly reduced chemical colon carcinogenesis in rats $(p<0.01)$. Rofecoxib in lower doses had the same effect on adenomas $(p<0.05)$ with no effect on adenocarcinomas. Rofecoxib reduced COX-2 expression in tumoral tissue from adenomas and adenocarcinomas $(\mathrm{p}<0.01)$.

Conclusions: rofecoxib prevents chemical colon carcinogenesis in the rat, with a reduction of tumoral colonic percentage in adenocarcinomas and tumoral COX-2 expression.
\end{abstract}

Key words: Rofecoxib. ASA. Colorectal cancer. Rat. Adenocarcinoma. Cyclooxygenase.

Noguera Aguilar JF, Amengual Antich I, Plaza Martínez A, Ibarra de la Rosa J, Tortajada Collado C, Gamundí Gamundí A, Pujol Tugores JJ. Cyclooxigenase-2 inhibition in colon experimental carcinogenesis. Rev Esp Enferm Dig 2005; 97: 637-647.

\section{Recibido: 10-11-04.}

Aceptado: 19-04-05.

Correspondencia: José Francisco Noguera Aguilar. Hospital Son Llàtzer. Ctra. de Manacor, km 4. 07198 Son Ferriol. Baleares. Fax: 971202173. e-mail: jnoguera@hsll.es

\section{INTRODUCTION}

There are basically two strategies for the prevention of colorectal cancer (CRC): early detection of the disease and premalignant lesions, and chemoprevention. Early treatment of premalignant or early-stage malignant lesions decreases the incidence and mortality from CRC (1-3). Chemoprevention is the use of chemical agents (pharmacological or not) to prevent the development of the carcinogenesis process. Various agents have been proposed as potential chemopreventive agents for CRC, including drugs such as COX inhibitors.

There is increasing evidence to suggest that acetylsalicylic acid and other nonsteroidal anti-inflammatory drugs (NSAIDs) reduce the risk of colorectal cancer. This observation is supported by both animal and human studies. Intervention data from familial adenomatosis coli establish that the process of human colonic adenoma polyp formation is affected by NSAIDs. A reduced risk has been found in both men and women for cancers of the colon and the rectum, and for the use of both ASA and other NSAIDs. The molecular mechanisms responsible for this chemopreventive action are not fully established, but there is a need to establish the dose, duration and frequency of use required for cancer-preventive activity (4).

Cyclooxygenase (COX) is an enzyme that catalyzes the first steps in the synthesis of prostaglandins from arachidonic acid. There are two COX isoforms, which are structurally similar and catalyze the same chemical reaction, but which have different sites and times of action: COX-1 is constitutional, and is always expressed by all tissues, whereas COX-2 is inducible by various stimuli, generally associated with inflammation (acute and chronic) (5-7).

The activity of COX-2 appears to be related to neoplastic proliferation in aberrant crypts of the colon by inhibiting apoptosis in tumor cells, inhibiting the function of natural killer (NK) T cells, and favoring tumor expan- 
sion by inducing angiogenesis within the tumor (8). Apoptosis inhibition is related to tumor development and metastasis induction, while angiogenesis is related to local tumor growth and progression.

An overexpression of COX-2 has been observed in colon tumors. Numerous studies have isolated the enzyme cyclooxigenase- 2 from the stroma of adenomas, and from the stroma and epithelium of CRCs (9-11), and some authors have even related the extent of COX-2 expression to CRC survival rates (12).

The aim of the present study was to assess whether selective and non-selective COX-2 inhibitors had an inhibitory effect on carcinogenesis as induced in the rat colon. As a secondary objective, a potential dose-dependent effect will be assessed by measuring two concentrations of the selective COX-2 inhibitor rofecoxib.

Rofecoxib possesses a much greater inhibitory effect than celecoxib, and has virtually no inhibitory effect on COX-1. Low doses of rofecoxib as employed in humans for acute and chronic pain are probably inefficient for the prevention of colon carcinogenesis, so we tested moderate and high doses of rofecoxib (1.2 and $3 \mathrm{mg} / \mathrm{kg})$. ASA has been previously employed at a dose of $10 \mathrm{mg} / \mathrm{kg}$ for the prevention of induced carcinogenesis, but the effect for this dose has been seen in colonic crypts, and has a minor influence over developed tumors (13-16). So we tested high-dose acetylsalicylic acid $-30 \mathrm{mg} / \mathrm{kg}$.

Chemical carcinogenesis was induced to determine the effect of rofecoxib on induced tumor development. Colon carcinogenesis using 1-2 DMH induces the formation of aberrant crypt foci in the intestinal epithelium and promotes carcinogenesis after said induction. This dysplasic epithelium overexpresses COX-2, and COX-2 specific inhibitors may have a suppressive effect on induced colonic tumors.

\section{MATERIAL AND METHOD}

Sixty-five male Sprague-Dawley rats (OFA-SD-hr, Criffa, Spain), with a mean weight of $230 \mathrm{~g}$ (range 190$280 \mathrm{~g}$ ), were used in the study. One week after acclimatization, the rats were distributed into four groups: a) control $(\mathrm{n}=20)$ with chemical carcinogenesis using 1-2 DMH (Sigma-Aldrich, Spain); b) ASA ( $n=15)$, with chemical carcinogenesis and the addition of acetylsalicylic acid at a dose of $30 \mathrm{mg} / \mathrm{kg}$; c) low-dose rofecoxib (n $=15)$, with chemical carcinogenesis and the addition of rofecoxib at a dose of $1.2 \mathrm{mg} / \mathrm{kg}$; and d) and high-dose rofecoxib $(n=15)$, with carcinogenesis and the addition of rofecoxib at a dose of $3 \mathrm{mg} / \mathrm{kg}$.

\section{Dietary and environmental conditions}

Environmental conditions at the animal-storage area were: $12 \mathrm{~h} / 12 \mathrm{~h}$ light/dark cycle (light from 8:00 am-8:00 pm); uniform temperature of $22 \pm 2{ }^{\circ} \mathrm{C}$, and relative humidity of $60-70 \%$. The diet provided was a maintenance diet supplemented with ASA at a dose of $600 \mathrm{ppm}$, and with rofecoxib at doses of $27 \mathrm{ppm}$ and $58 \mathrm{ppm}$. The rats were fasted prior to surgery, and no bowel preparation was performed.

The study complied with the guidelines established by European Directive 86/609/EEC on the protection of animals used in experimentation.

\section{Drug administration}

After eight days for acclimatization, colonic tumors were induced with 1-2 DMH by administering 18 weekly subcutaneous injections at a weekly dose of $25 \mathrm{mg} / \mathrm{kg}$ of weight, and antiinflammatories were administered PO with the oral diet.

\section{Follow-up and sacrifice}

Animals were examined weekly, paying special attention to their weight, abdominal perimeter, presence and quality of stools, and presence of rectal bleeding. All animals were sacrificed at week 20 using an anesthetic overdose, with an initial intramuscular injection of ketamine, atropine and diazepam (50, 10, 40\%, respectively) solution at a dose of $4 \mathrm{ml} / \mathrm{kg}$. A midline laparotomy was performed and the entire colon was removed from the anus to the cecum, including also $1 \mathrm{~cm}$ of the terminal small intestine. The pieces were fixed in a $10 \%$ formaldehyde solution for histological examination.

\section{Examination of colonic tumors}

In the bowel we determined three parameters: number of tumors, tumor surface area, and percentage of tumor surface area (percentage of colon area occupied by tumor tissue). Percentage of tumor was determined by estimating the total colon surface area versus the tumor surface area in the colon. A histological study of colonic samples also determined histological type of tumors, histological grade, tumor invasion, and lymph-node involvement.

\section{COX-2 colonic expression}

COX-2 expression was measured in colonic adenomas and adenocarcinomas, and in normal colonic tissue near the tumors. An anti-COX-2 antibody was used (Santa Cruz Biotech., USA) by immunohistochemistry, looking for the positivity or negativity of its expression and for its localization. 


\section{Statistical analysis}

The study data were analyzed using the SPSS and G-Stat programs, and the statistical analysis was performed using one-factor ANOVA models (Scheffé test) and Chi-squared tables. We considered significant $\mathrm{p}$ values at 0.05 .

\section{RESULTS}

The colonic tumors obtained in the 65 animals included in the study are analyzed below.

\section{Mortality}

The overall mortality rate in the study was $4.61 \%$ (3 out of 65 animals). There were two postoperative deaths in the control group, and another death occurred in the high-dose rofecoxib group, which were not replaced. Death was caused by a cerebral hemorrhage in the control group, and had no demonstrable cause in the rofecox$i b$ group, with no recuperation of the third animal for postmortem study.

\section{Alterations in colonic transit}

No alterations occurred in the gastrointestinal transit; a macroscopic study of the colon after animal sacrifice did not find any totally -or partially- stenosing neoplasms. Increases in body weight were either positive or nil, but never negative (Fig. 1).

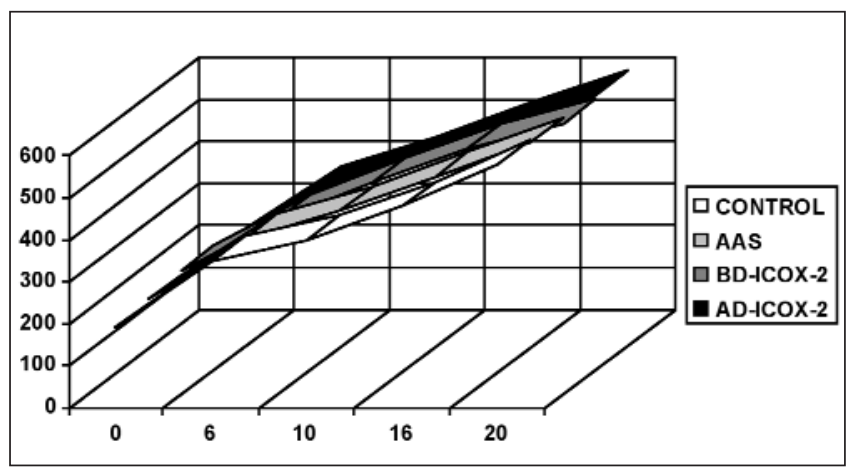

Fig. 1.- Curve of body-weight increases in the study groups. Curvas de crecimiento en los grupos de estudio.

\section{Number of tumors}

A total of 97 colonic tumors were found in the 62 animals studied, with a mean of 1.56 tumors per animal; 72 were malignant tumors (adenocarcinomas) and 25 were adenomas. The mean number of adenomas per animal was 0.40 , whereas the mean number of adenocarcinomas was 1.16. The distribution of these tumors is shown in table I. Differences were significant in the number of colonic adenocarcinomas between groups. In the control group, the mean number of colonic adenocarcinomas was 1.55 tumor per rat, while in the high-dose rofecoxib and ASA groups this was 0.86 , a significant difference with a $\mathrm{p}$ value $<0.05$ (Scheffé test). The low-dose rofecoxib group had a mean number of adenocarcinomas of 1.2, with no significant differences versus the other groups.

Regarding colonic adenomas, the control group had the highest incidence with 0.65 adenomas per rat. In the ASA group, mean incidence was 0.53 , in the high-dose rofecoxib group it was 0.38 , and for low-dose rofecoxib the incidence of adenomas was nil. This latter group showed a significant difference versus the control group ( $\mathrm{p}<0,05$, Scheffé test).

With regard to the location of colonic tumors, most occurred in the distal colon $(57.14 \%$ in the distal $5 \mathrm{~cm}$ of the large bowel).

Table I. Overall and mean values in colonic induced tumors

\begin{tabular}{lcccc}
\hline & $\begin{array}{c}\text { Number } \\
\text { adenocar. }\end{array}$ & $\begin{array}{c}\text { Mean } \\
\text { adenocar. }\end{array}$ & $\begin{array}{c}\text { Number } \\
\text { adenomas }\end{array}$ & $\begin{array}{c}\text { Mean } \\
\text { adenomas }\end{array}$ \\
\hline Control & 28 & 1.55 & 12 & 0.65 \\
ASA & 13 & $0.86^{*}$ & 8 & 0.53 \\
LD-COX-2 Inh. & 18 & 1.28 & 0 & 0 * \\
HD-COX-2 Inh. & 13 & $0.86^{*}$ & 5 & 0.38 \\
\hline
\end{tabular}

*Significant difference in relation to control group.

\section{Microscopic tumor surface area}

Total colon tumor surface area for all animals included in the study was $31.56 \mathrm{~cm}^{2}-0.12 \mathrm{~cm}^{2}$ corresponded to benign tumors and the rest, $31.44 \mathrm{~cm}^{2}$, to adenocarcinomas. Mean tumor surface area was lower for adenocarcinomas in the high-dose rofecoxib group, but showed no relevant differences between groups.

Mean tumor area for adenomas was higher in the control group, $0.27 \mathrm{~cm}^{2}$ versus the other groups (ASA 0.13 $\mathrm{cm}^{2}$, low-dose rofecoxib $0 \mathrm{~cm}^{2}$, and high-dose rofecoxib $\left.0.11 \mathrm{~cm}^{2}\right)$. The difference between groups was not relevant (Table II).

Table II. Mean values for colonic area and percentage of colonic area in colonic tumors

\begin{tabular}{lcccc}
\hline & $\begin{array}{c}\text { Tumor } \\
\text { surface } \\
\text { adenocar. }\end{array}$ & $\begin{array}{c}\text { Tumor } \\
\text { percentage } \\
\text { adenocar. }\end{array}$ & $\begin{array}{c}\text { Tumor } \\
\text { surface } \\
\text { adenoma }\end{array}$ & $\begin{array}{c}\text { Tumor } \\
\text { percentage } \\
\text { adenoma }\end{array}$ \\
\hline Control & 0.45 & 4.56 & 0.27 & 0.21 \\
ASA & 0.34 & 2.94 & 0.13 & 0.17 \\
LD-COX-2 Inh & 0.40 & 3.52 & $0 *$ & $0 *$ \\
HD-COX-2 Inh & 0.38 & $0.55^{*}$ & 0.11 & 0.09 \\
\hline
\end{tabular}

*Significant difference in relation to control group. 


\section{Microscopic tumor percentage}

Percentage results for adenomas were virtually negligible, since they accounted for only $0.11 \%$ of total colon surface area.

Considering colonic adenocarcinomas, we observed that the highest percentage was obtained in the control group, $4.56 \%$, whereas it decreased slightly in the groups receiving ASA and low-dose rofecoxib to 2.94 and $3.52 \%$, respectively, and was practically negligible in the group receiving high-dose rofecoxib, with a value of $0.55 \%$. These differences were significant when the latter group was compared to the control group and the lowdose rofecoxib group ( $\mathrm{p}<0.01$, Scheffé test) (Fig. 2).

For colonic adenomas, results are similar to those obtained for tumor surface. The control group had the highest mean tumor percentage $(0.21 \%$ in the control group, $0.17 \%$ in the ASA group, $0 \%$ in the low-dose rofecoxib group, and $0.09 \%$ in the high-dose rofecoxib group). Only differences between the control and low-dose rofecoxib groups were statistically significant $(\mathrm{p}<0.05$, Scheffé test) (Fig. 2).

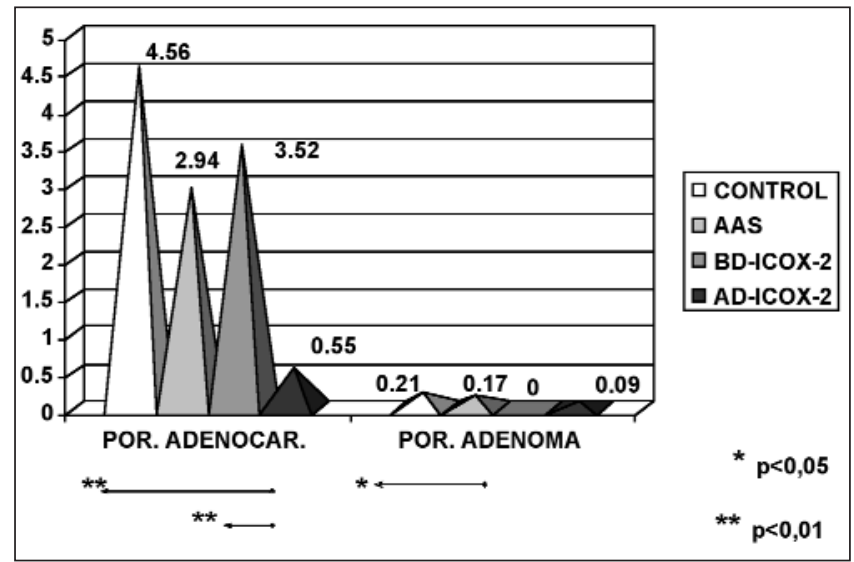

Fig. 2.- Percentage of tumor area for adenomas and adenocarcinomas. Porcentaje tumoral de adenomas y adenocarcinomas en los grupos de estudio.

\section{COX-2 colonic expression}

This immunohistochemical determination was measured in colonic tumor tissue and the normal mucosa near the tumor. COX-2 expression was 6 times greater in adenocarcinomas, with a mean value of 0.0043 in adenomas and 0.27 in malignant tumors, a significant difference $\left(\mathrm{p}<0.01, \chi^{2}\right)$.

In colonic adenocarcinomas a reduction in COX-2 expression was detected for low (and high) dose rofecoxib in relation to the ASA and control groups $\left(p<0.001, \chi^{2}\right)$ (Table III). This lower expression was only seen in the stroma and epithelium of adenocarcinomas but not in normal colonic tissue.
The same was detected for adenomas -COX-2 expression in adenomas showed a significant reduction in the rofecoxib group $\left(\mathrm{p}<0.01, \chi^{2}\right)$ (Table III).

When the overall results of COX-2 expression for adenomas and adenocarcinomas are analyzed, only the highdose rofecoxib group showed significant reductions versus the control and ASA groups $\left(\mathrm{p}<0.05, \chi^{2}\right)$.

Table III. COX-2 expression in colonic adenomas, colonic adenocarcinomas and normal colonic mucosa

\begin{tabular}{lcccc}
\hline & $\begin{array}{c}\text { Tumor } \\
\text { COX-2 } \\
\text { adenocar. }\end{array}$ & $\begin{array}{c}\text { Overall } \\
\text { COX-2 } \\
\text { adenocar. }\end{array}$ & $\begin{array}{c}\text { Tumor } \\
\text { COX-2 } \\
\text { adenomas }\end{array}$ & $\begin{array}{c}\text { Overall } \\
\text { COX-2 } \\
\text { adenomas }\end{array}$ \\
\hline Control & 0.25 & 0.44 & 0.46 & 0.66 \\
ASA & 0.38 & 0.91 & 0.37 & 0.71 \\
LD-COX-2 Inh. & $0 *$ & 0.43 & $0^{*}$ & 0 \\
HD-COX-2 Inh. & $0.005^{*}$ & 0.3 & $0^{*}$ & 0.14 \\
\hline
\end{tabular}

\section{Histological study}

Adenomas $(n=25)$ accounted for $25.77 \%$ of all tumors induced, and the remainder were adenocarcinomas (74.22\% of neoplasms). Adenocarcinomas were well differentiated in $33.33 \%$ of cases, moderately differentiated in $37.5 \%$, and poorly differentiated in $29.16 \%$ of cases. Lymphoid hyperplasia was found in association with any of the above situations with no relevant differences.

Regarding the extent of invasion in adenocarcinomas, most reached the submucosa $(57.14 \%)$, and $42.85 \%$ invaded beyond the submucosa. A total of 344 epicolonic nodes (5.54 per rat, 4.77 per adenocarcinoma) were isolated, $18(5.23 \%)$ of which contained adenocarcinoma micrometastases. None of the differences between groups regarding these parameters were significant.

\section{DISCUSSION}

Some studies have been published evaluating NSAIDs in the chemoprevention of drug-induced CRC in animal models, showing that NSAIDs reduce the incidence and multiplicity of these tumors (17-19).

The efficacy of COX-2 selective inhibitors for CRC in animals derives from studies conducted in Min (Multiple Intestinal Neoplasia) mice with a dominant mutation in the APC (Adenomatous Colon Polyposis) gene, which is characterized by the development of multiple intestinal adenomas at an early age (20). In these animals, the administration of celecoxib causes a greater reduction in the number of adenomas when compared to piroxicam. The administration of rofecoxib also causes similar effects in these mice (20-23). Subsequent studies have found a reduction of aberrant colon crypt foci by $40-49 \%$, and significant reductions in the incidence of $\mathrm{CRC}$ and its multi- 
plicity when celecoxib was administered in animals exposed to a carcinogen. Few studies of rofecoxib have been reported, which has a 2 times greater selectivity for COX-2 than celecoxib $(24,25)$.

Rofecoxib undergoes rapid absorption in rats, and dose increases greater than $5 \mathrm{mg} / \mathrm{kg}$ result in no increased drug plasma levels in the rat (26). It is primarily excreted in the bile, and drug metabolites are not active in terms of cyclooxygenase 1 or 2 inhibition (27). The doses used in this study, $1.2 \mathrm{mg} / \mathrm{kg}$ and $3 \mathrm{mg} / \mathrm{kg}$, are high when compared to typical doses as used in arthritis and acute pain, but according to clinical studies on pharmacokinetics, COX-2 inhibition is greater at higher doses, and the tolerability of these high doses was acceptable (28).

In October 2004, rofecoxib was withdrawn by MSD to avoid some cardiovascular events found in the APPROVe study on the prevention of colonic adenomas in humans. This withdrawal affects clinical use, but the investigation of selective COX-2 inhibitors in CCR must continue, and rofecoxib is the drug with the highest power for COX-2 inhibition.

Most studies only refer to the number of colon tumors and omit parameters as important as tumor surface area and percentage. As we are not referring to aberrant crypt or dysplasic foci, but induced colon tumors, we believe that the microscopic tumor percentage should be evaluated, as it is the most reliable indicator of induced carcinogenesis and the only parameter relating the amount of tumor tissue to the size of the colon studied. The carcinogenic experimental model used here is widely accepted in animal experimentation for CRC $(29,30)$, with around $60 \%$ of induced tumors being found in the distal large bowel with a similar distribution to that seen in humans (31).

For induced colonic adenomas we found that the number of tumors and tumor percentage were significantly lower in the group with low-dose rofecoxib. In spite of the low incidence of adenomas in the study, we can observe an important reduction of benign tumors in the group with a low-dose COX-2 inhibitor.

In relation to induced colonic adenocarcinomas, we have found a significant reduction in their number when ASA and high-dose rofecoxib were given. When the percentage of tumor surface is analyzed, only high-dose rofecoxib showed a significant reduction. Low-dose rofecoxib did not show a significant reduction in adenocarcinomas as opposed to the results for adenomas. These results agree with those recently published by Oshima et al. thus proving that rofecoxib induces a dose-dependent reduction in the number and size on induced colonic tumors (22).

The reduction in induced carcinogenesis caused by COX-2 inhibition has been accompanied by significant reductions in COX-2 expression, as measured by immunohistochemistry in colonic tumors.

With our results, prevention results from the addition of high-dose rofecoxib in colonic induced adenocarcino- mas in rat models. Low-dose rofecoxib showed this same effect in benign tumors -colonic adenomas. May we say that non-selective COX-inhibitors such as ASA or selective COX-2 inhibitors at low doses are inefficient to prevent colonic carcinogenesis? In this study we chose $30 \mathrm{mg} / \mathrm{kg}$ of ASA since in previous studies doses of $10 \mathrm{mg} / \mathrm{kg}$ were useless or only caused a decreased promotion of dysplasic colonic crypts $(13-16,32)$, but with no a clear effect on colonic neoplasms $(33,34)$.

Recently, Becerra et al. (13) found increased toxicity and lack of efficacy regarding rofecoxib in combination with chemotherapy in the treatment of metastatic colorectal cancer. The dose of rofecoxib employed in their clinical study was $50 \mathrm{mg} / \mathrm{day}$; with this dose, the potential reduction of carcinogenesis was not reached. In our opinion, a dose of $50 \mathrm{mg} /$ day of rofecoxib is insufficient. The dose that we have found to be effective in the reduction and prevention of pharmacologically induced colonic carcinogenesis was $3 \mathrm{mg} / \mathrm{kg} /$ day. Rofecoxib at a dose of 25 or $50 \mathrm{mg} /$ day is useful for acute and chronic pain, but if we want an effect on the prevention of colorectal cancer, doses must be higher.

These experimental results will need further clinical studies to investigate these doses in human colorectal cancer. We think that additional studies with more patients are needed, including studies with higher doses of rofecoxib, to clarify the role of rofecoxib in colorectal cancer.

\section{ACKNOWLEDGEMENTS}

We are grateful to Departamento de Fisiología Animal, Universitat de les Illes Balears (Prof. R. Rial) for their laboratory and environmental support.

\section{REFERENCES}

1. Lieberman DA. Screening for colorectal cancer. Clin Cornerstone 2002; 4: 1-10.

2. Benamouzig R, Chaussade S. La chimioprevéntion du cancer colorectal. Presse Med 2002; 31: 124-8.

3. Sheehan KM, Sheahan K, O'Donoghue DP, MacSweeney F, Conroy RM, Fitzgerald DJ, et al. The relationship between cyclooxygenase-2 expression and colorectal cancer. JAMA 1999; 282 (13): 1254-7.

4. Arber N. Do NSAIDs prevent colorectal cancer? Can J Gastroenterol 2000; 14(4): 299-307.

5. Vane JR, Bakle YS, Botting RM. Cyclo-oxygenases 1 and 2. Annu Rev Pharmacol Toxicol 1998; 38: 97-120.

6. Brooks P, Emery P, Evans JF, Fenner H, Hawkey CJ, Patrono C, et al. Interpreting the clinical significance of the differential inhibition of cyclo-oxygenase-1 and cyclo-oxygenase-2. Rheumatology 1999; 38: 779-88.

7. Lipsky PE, Brooks P, Crofford LJ, DuBois R, Graham D, Simon LS, et al. Unressolved issues in the role of cyclooxygenase- 2 in normal physiologic processes and disease. Arch Intern Med 2000; 160: 91320.

8. Williams CS, Mann M, DuBois R. The role of cyclo-oxygenases in inflammation, cancer and development. Oncogene 1999; 18: 7908-16.

9. DuBois RN, Radhika A, Reddy BS, Entingh AJ. Increased cyclooxygenase-2 levels in carcinogen-induced rat colonic tumors. Gastroente- 
rology 1996; 110: 1259-2.

10. Bamba H, Ota S, Kato A, Adachi A, Itoyama S, Matsuzaki F. High expression of cyclooxygenase-2 in macrophages of human colonic adenoma. Int $\mathrm{J}$ Cancer 1999; 83: 470-5.

11. Reddy BS, Hirose Y, Lubet R, Steele V, Kelloff G, Paulson S, et al. Chemoprevention of colon cancer by specific cyclooxygenase-2 inhibitor, celecoxib, administered during different stages of carcinogenesis. Cancer Res 2000; 60: 293-7.

12. Kargman SL, O'Neill GP, Vickers PJ, Evans JF, Mancini JA, Jothy S. Expression of prostaglandin G/H synthase -1 and -2 protein in human colon cancer. Cancer Res 1995; 55: 2556-9.

13. Becerra CR, Frenkel EP, Ashfaq R, Gaynor RB. Increased toxicity and lack of efficacy of rofecoxib in combination with chemotherapy for treatment of metastatic colorectal cancer: a phase II study. Int J Cancer 2003; 105: 868-72.

14. Pence BC, Dunn DM, Zhao C, Landers M, Wargovich MJ. Chemo-preventive effects of calcium but not aspirin supplementation in cholic acid-promoted colon carcinogenesis: correlation with intermediate endpoints. Carcinogenesis 1995; 16 (4): 757-65.

15. Mereto E, Frencia L, Ghia M. Effect of aspirin on incidence and growth of aberrant crypt foci induced in the rat colon by 1,2-di-methylhydrazine. Cancer Lett 1994; 76 (1): 5-9.

16. Escribano M, Molero L, López-Farre A, Abarrategui C, Carrasco C, García-Méndez A, et al. Aspirin inhibits endothelial nitric oxide synthase (eNOS) and Flk-1 (vascular endothelial growth factor receptor-2) prior to rat colon tumour development. Clin Sci 2004; 106 (1): 83- 91 .

17. Kune GA, Kune S, Watson LF. Colorectal cancer risk, chronic illnesses, operations and medications.: case control results from the Melbourne Colorectal Cancer Study. Cancer Res 1988; 48: 4399-404.

18. Wargovich MJ, Chen CD, Harris C. Inhibition of aberrant crypt growth by nonsteroidal antiinflammatory agents an differentiation agents in the rat colon. Int J Cancer 1995; 60: 515-9.

19. Rao CV, Rivenson A, Simi B, Zang E, Kelloff G, Steele V, et al. Chemoprevention of colon carcinogenesis by sulindac, a nonsteroidal antiinflammatory agent. Cancer Res 1995; 55: 1464-72.

20. Su LK, Kinzler KW, Vogelstein B, Preisinger AC, Moser AR, Luongo C, et al. Multiple intestinal neoplasia caused by a mutation in the murine homolog of the Apc gene. Science 1992; 256: 668-70.

21. Jacoby RF, Seibert K, Cole CE, Kelloff G, Lubet RA. The cyclooxygenase- 2 inhibitor celecoxib is a potent preventive and therapeutic agent in the min mouse model of adenomatous polyposis. Cancer Res 2000; 60: 5040-4.

22. Oshima M, Murai N, Kargman S, Arguello M, Luk P, Kwong E, et al. Chemoprevention of intestinal polyposis in the Apc?? ${ }^{716}$ mouse bymouse by rofecoxib, a specific cyclooxygenase-2 inhibitor. Cancer Res 2001; 61: 1733-40.

23. Evans JF. Rofecoxib (vioxx), a specific cyclooxygenase- 2 inhibitor, is chemopreventive in a mouse model of colon cancer. Am J Clin Oncol 2003; 26 (4): 62-5.

24. Reddy BS, Rao CV, Seibert K. Evaluation of cyclooxygenase-2 inhibitor for potential chemopreventive properties in colon carcinogenesis. Cancer Res 1996; 56: 4566-9.

25. Kawamori T, Rao CV, Seibert K, Reddy BS. Chemopreventive activity of celecoxib, a specific cyclooxygenase-2 inhibitor, against colon carcinogenesis. Cancer Res 1998; 58: 409-12.

26. Halpin RA, Geer LA, Zhang KE, Marks TM, Dean DC, Jones AN, et al. The absorption, distribution, metabolism and excretion of rofecoxib, a potent and selective cyclooxygenase- 2 inhibitor, in rats and dogs. Drug Metab Dispos 2000; 28 (10): 1244-54.

27. Nicoll-Griffith DA, Yergey JA, Trimble LA, Silva JM, Li C, Chauret N, et al. Synthesis, characterization, and activity of metabolites derived from the cyclooxigenase-2 inhibitor rofecoxib (MK-0966, Vioxx). Bioorg Med Chem Lett 2000; 10 (23): 2683-6.

28. Depre M, Ehrich E, Van Hecken A, De Lepeleire I, Dallob A, Wong P, et al. Pharmacokinetics, COX-2 specificity, and tolerability of supratherapeutic doses of rofecoxib in humans. Eur J Clin Pharmacol 2000; 56 (2): 167-74

29. Vinas Salas J, Pinol Felis C, Ferminan A, Egido R, Pérez-Holanda S, Biendicho $\mathrm{P}$, et al. Repetitive mucosal trauma promotes colon cancer in experimental rat model. Rev Esp Enferm Dig 2001; 93 (3): 140-7.

30. Bayon Lara AM, Landa García I, Alcalde Escribano J, Rodríguez Dapena S, Ortega Medina L, Balibrea Cantero JL. Carcinogénesis colónica en ratas vagotomizadas. Rev Esp Enferm Dig 2001; 93 (9): 576-86.

31. Linares Santiago E, Sánchez Calzado JA, Capitán Morales L, Gómez Parra M, González Mariscal MJ, Mendoza Olivares FJ, et al. Relación entre el grado de diferenciación celular del cáncer colorrectal y su distribución topográfica. Rev Esp Enferm Dig 2002; 94 (2): 78-87.

32. Bak AW, McKnight W, Li P, Del Soldato P, Calignano A, Cirino G, et al. Cyclooxygenase-independent chemoprevention with an aspirin derivative in a rat model of colonic adenocarcinoma. Life Sci 1998; 62 (23): 367-73.

33. Barnes CJ, Lee M. Determination of an optimal dosing regimen for aspirin chemoprevention of 1,2dimethylhydrazine-induced colon tumours in rats. Br J Cancer 1999; 79 (11-12): 1646-50.

34. Reddy BS, Rao CV, Rivenson A, Kelloff G. Inhibitory effect of aspirin on azoxymethane-induced colon carcinogenesis in F344 rats. Carcinogenesis 1993; 14 (8): 1493-7. 